\title{
The Effect Of Brand Experience Provider On Brand Experience: Focus On Korean Cosmetic Brand Shop
}

\author{
Gap Yeon Jeong, Kyungpook National University, South Korea \\ Chae Chang Im, Hankuk University of Foreign Studies, South Korea \\ Min Suk Kim, Hankuk University of Foreign Studies, South Korea
}

\begin{abstract}
This present research distinguishes brand experience providers of cosmetic companies that include three elements: Brand identity elements of cosmetic brand shops (feminine and environmental-friendly brand identity); Marketing mix elements (level of iconic product, level of steady-seller product, reasonable pricing, convenience of location, quality of additional service); Cosmetic brand store elements (effective product assortment, atmosphere of a store, availability of testers, proficiency of consultants). This paper aims to explore these elements and the effect of brand experience provider on all brand experience dimensions; sensory, affective, intellectual, and behavioral experience. After the review of extant studies, we propose 11 hypotheses.

Based on the collected 295 consumers of experienced cosmetic brand shop, the proposed model is testified with the SPSS 15.0 and AMOS 7.0 is supported. According to the result of empirical analysis, it turns out that, in terms of characteristics of brand experiential provider, 'feminine brand identity', 'iconic product', 'steady seller product', 'convenient location', 'additional service quality', 'assortment', 'atmosphere', 'self-tester', and 'consultant' affected the customers' holistic brand experience of cosmetic brand shop. However, 'environmental-friendly brand identity', 'reasonable price' results to have no influence on the holistic brand experience of brand of cosmetic brand shop. The study produced a theoretical implication on brand experience that it empirically approached to factors of brand experiential provider on holistic brand experience of store. The earlier studies were at best conceptual analysis or they mainly dealt with in-store factor, whereas this paper divides factors that affect the customer's overall experience into 'brand identity', 'marketing mix strategy', and 'physical environment of in-store'.
\end{abstract}

Keywords: Cosmetic Brand Shop; Brand Experience Provider; Brand Experience

\section{INTRODUCTION}

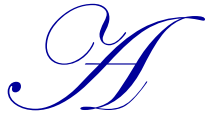

$\mathrm{t}$ the beginning, low-end cosmetics brands led the formation of Korean cosmetic brand shop market with their unique concept represented by packing and distribution cost reduction and differentiation strategies for the brand image and product ingredients and quality. However, as Amore Pacific, LG Household \& Health Care Ltd., and other large cosmetics companies have recently come into the market, brand shops - stock only one brand or a selection of named brands - has dominated the distribution channels which were once based on cosmetic shops. And the trend has led to quantitative expansion and fierce competition. Under the circumstances, brand shops should offer visual stimuli to help customers see efforts of companies or salespeople and have a unique experience with the brand. The most influential stimulus is a store physical environment where consumption occurs (Baker, 1987; Bitner, 1992).

Customers actively interact with store physical environment while making purchasing decisions. At the point of consumption, the store physical environment provides various information and it encourages a new way of decisionmaking (Namasivayam \& Mattila, 2007). Put differently, store physical environments including color, light, style, music, and fragrance give unexpected information to customers and lead them to another way of decision-making (Hopkins, Grove, Raymond, \& LaForge, 2009). Studies on store's physical environments have focused on the two 
aspects: 1) the direct effects on consumer satisfaction, perceived quality, and other consumers' reactions 2) the indirect effects through the medium of consumer feeling, value perception, and consumer psychological factors (Bloemer \& Ldrkerken-Schroder, 2002; Guenzi, Johnson, \& Castaldo, 2009; Lin, 2010; Namasivayam \& Mattila, 2007; Vilnai-Yavets \& Rafaeli, 2006; Wakefield \& Blodgett, 1996). The store's physical environment provides sensory and affective experience and encourages them to have an unusual experience while buying and using goods and have a favorable attitude toward the brand (Schmitt, 2003). In this regard, cosmetic brand shops provide store physical environment where consumers can have various experiences with the brand, and attract new customers, leading to sales up and business performance improvement.

Consumers experience a brand when they explore the brand or purchase products or receive services and when consumption occurs (Brakus, Josko, Schmitt \& Zarantonello et al., 2009). In other words, consumer's brand experience encompasses from purchasing process to indirect experiences based on advertisement, communication and website visit. It doesn't occur but is generally evoked by brand-related stimuli (Brakus et al., 2009) Therefore, cosmetics companies should facilitate experience provider which gives positive brand experience to consumers. Corporate can use experience providers as marketing strategies aiming to achieve marketing objectives in their target market. For corporate, experience providers are controllable marketing mix variables which they provide to receive consumer response they want (Schmitt, 1999).

Recent studies conducted factor analysis, mostly focusing on the effects of store's physical environment on consumer's brand experience (Bagdare, 2013; Davis, 2012; Grewal, Levy, \& Kumar, 2009; Verhoef et al. 2009). However, consumer brand experience can be evoked not only by brand-related interactions such as store's physical environment and purchasing products, but also by brand-related stimuli such a brand's design, identity, packaging, and marketing communication (Brakus et al., 2009). Likewise, various marketing communications and brand-related stimuli provide brand experience to consumers. Still there is a lack of empirical studies on a connection between brand experience providers and brand experience. As the market is becoming more and more competitive, it is particularly true for cosmetics brand shops to offer unique brand experience providers to customers and promote emotional relationship in a sustainable manner, in order to enhance their competitive edge. Therefore, this study objective is to investigate the difference of consumer's behavior evoked by marketing strategies. Schmitt (1999) proposed that companies need to implement various strategies including product experience, store's environment and image, and experiential communication in order to promote positive brand experience. In the study of Brakus et al. (2009), brand experience is sensory, affective, intellectual, and behavioral responses evoked by brand-related stimuli and it needs to be coupled with brand experience providers including visual and verbal brand identity and communication.

Cosmetic brand shops are particularly represented by providing target consumers brand identity which appeals to their feeling and needs. Cosmetic products have a number of characteristics: the target consumer is mostly women and the products are directly used on their skin. Thus, cosmetics companies use logo, slogan and other visual and verbal factors to deliver brand identity that can appeal to the consumer's feeling and cognition and reflect the consumer's demand of eco-friendly products by providing coherent brand image (Dolbec \& Chebat, 2013). Moreover, cosmetic brand shops promote their iconic products and steady-sellers as the brand's main products; create a sense of trust among consumers. In cosmetic brand shops, you can logically display a mix of products to help customers easily find the product they want and have direct experience with the product (Bonfrer \& Chintagunta, 2004). In fact, the reports released by TNEX and TNS show that the characteristics of cosmetic brand shops are brand's feminine and environmental-friendly identity, providing iconic product and steady seller product, celebrity commercial campaign, logical assortment of product lines, proficient and reliable consultants, and the availability of cosmetic testers in store.

Thus, this study looks into the brand experience providers which are findings in the precedent research and the characteristics of the cosmetic brand shops. Based on that, the research examines the brand experience providing factors from brand identity(feminine and environmental friendly), marketing mix variables(iconic product and steady seller product), reasonable price, convenient location, additional service quality, and store's physical environment(assortment of products, atmosphere, testers, proficiency of consultants), and how those factors affect all brand experience dimensions: sensory, affective, intellectual, and to behavioral experience. 


\section{THEORETICAL BACKGROUND}

\subsection{Brand Experience Providers}

Consumers can have a brand experience as they examine the brand, purchase a product, receive services, and use the product (Brakus et al., 2009). That encompasses a direct experience such as consumption experience and an indirect experience including exposure to ads, communication, and website visit. The brand experience is not created automatically but induced by companies (Brakus et al., 2009). Thus, customer experience management (CEM) of the firms has attracted a lot of attention because brand experiences are evoked as consumers get brand information and even after the purchase of a product.

CEM is a strategic process employed by a firm to manage its customers' entire experience about products and services provided by the firm. It aims to lead a customer-centered innovation rather than a transformation of the corporate structure and culture (Meyer \& Schwager, 2007). CEM is a higher level of strategy than customer relationship management (CRM). CRM is designed to help a business understand customers' needs and purchasing behaviors and building relationships with them to identify sales opportunities. Unlike CRM, CEM aims to create a database of customers' experience by examining each step of consumer contact to understand how they feel about the brand and what they think of the brand. To this end, businesses must offer experience providers according to each step based on the database, in order to help consumers have positive experience throughout the entire process of communication with the brand.

The brand experience providers is a tactical marketing tool to achieve marketing goal in a company's target market and a set of controllable marketing variables that a company provides to attract intended responses from its customers (Schmitt, 1999). Marketing factors that earlier studies on consumer's brand experience suggested focused on how companies can successfully provide the entire experience of a brand to providers. However, Schmitt (1999) has indicated that in order to evoke positive consumer's brand experience, companies need to implement strategic product experience, store's physical environment and atmosphere, and experiential communication.

First, product experience occurs before and after point of purchase and it consists of functional, experiential, and authentic experience (Schmitt 2003). Product experience delivers brand value through consumer's direct and indirect interaction with the brand. Thus, if a company provides successful product experience, it would have a positive influence on product attitudes, purchase intent, and preference (Hoch, 2002). Second, Store's physical environment and atmosphere is a strategic implementation to deliver brand positioning to target customers (Schmitt, 2003; Veryzer \& Hutchinson, 1998). Coherent and differentiated store's physical environment and atmosphere can create strong and favorable brand image among target customers (Keller, 2008). Last, experiential communication is a channel to convey brand value to target customers. It not only delivers objective information but also affective pleasure of a product to consumers (Schmitt, 2003). As companies successfully implement and manage those three factors, consumers can complete entire brand experience by having sensory, affective, behavioral, and intellectual experience (Schmitt, 1999).

In addition, Berry, Wall, \& Carbone (2006) explained that a service experience clue is anything in the service experience the customer perceives by its presence - what they see, hear, tasted, or smell. And it generally falls into three categories such as functional clue, mechanic clue, and human clue. For starters, functional clues are the easiest one for consumers to figure out and understand and concern the technical quality of the brand - functionality, reliability, and competence of the brand. Next, mechanic clues unconsciously come from physical factors that consumers determine first impression of a brand and even sensory presentation. They include visual presentation such as fixtures, facilities, furniture disposition, lights, and other clues that unconsciously interact with consumers. Lastly, human clues come from the behavior and appearance of service providers including choice of words, tone of voice, level of enthusiasm, body language, neatness, and appropriate dress. In general, functional clues are rational and consciously perceived by customers and the other two are more emotional and unconsciously perceived by customers. Thus, the three types of clues are important in influencing consumers' overall perceptions of the experience (Berry et al., 2006). 
Brakus et al. (2009) systematized and classified types of brand experience, showing that brand experience is sensory, affective, intellectual, and behavioral responses evoked by brand-related stimuli. In order to elicit those reactions from consumers, brand identity and brand communication as part of a brand experience providers are needed. Brand identity represents how the brand wants to be perceived and it leads brand (Aaker, 1996). It is a strategic tool for a company to establish concept and target of a brand in an attempt to be perceived as the company wants (Kapferer, 1997). The development and implementation of a brand identity is an integrated management process of all components to establish an appropriate brand positioning within consumers' perceptions. The process mainly comprises the developments of visual and verbal elements (Keller, 2009). Among those visual and verbal elements of brand identity, there are colors, shapes, typefaces, designs, slogans, mascots, brand characters, brand name, and logo (Brakus et al., 2009). Those various elements of brand identity can provide a flexible impression but it can also deliver an ambiguous impressions. Meanwhile, coherent brand identity can give a neat and well-managed impression, and it still can deliver inflexible atmosphere (Ruzzier \& de Chenatony, 2013).

Brand communication refers a marketing communication activity including pricing, promotion, PR, advertisement, events, and sponsorship, which businesses performs to build and accumulate its brand asset (Keller, 2009). It also refers to companies' intentional activities to promote connecting and sharing with their customers as part of an effort to build brand awareness and ultimately sell its products (Heinonen \& Strandvik, 2005). In particular, brand communication elements in stores are TV ads, packaging, online brochure, and store's image (Zarantonello et al., 2007). Further studies, based on the brand identity and communications, were designed to figure out how differently experience providers affect consumers' brand experience in a variety of settings. In particular, considering the fact that stores deliver enormous information to customers to have brand experience and are the ideal interface between a company and its consumers, businesses are put more importance on their brand stores. Thus, many studies have focused on the effects of the store's physical environment on consumer's brand experience (Ofir \& Simonson, 2007).

In addition, Grewal et al. (2009) looked into the environment factors of the brand store in macro view and it turned out that sales promotion, pricing, merchandizing, supply chain, and the location of the store deliver positive experience to consumers, and it can lead to consumer satisfaction, frequent visits to the store, more purchases, and ultimately higher profits of the company. Verhoef et al. (2009) suggests that social environment, service interaction, store's atmosphere, product assortment, pricing, consumers' experience with other distribution channel, product lines in the stores, and previous consumer experience has a impact on consumers' positive experience in brand stores. Davis (2012) conducted in-depth interview and examined stores' environmental aspects that affect shopping experience of the northwestern Chinese consumers. The results show that the atmosphere and interior design of stores, social environment, services, and merchandising influence Chinese consumers' shopping experience. And Bagdare (2013) pointed out four factors - the store's atmosphere, convenience, staff and relationship oriented culture - as the elements of the brand store that affect customers' positive experience, and empirically analyzed the correlation between the four factors and customers' experience. As a result, four factors have all positive influence on customers' experience in the brand stores, and store's atmosphere is most influential among those factors.

Studies were also carried out to find out the effective experience providers on consumers' brand experience in a variety of settings. Roswinanto (2011) conducted an empirical study to look into the advertisements of relevant brands and figure out the effective factors on consumers' brand experience. And it suggests that consumers' attitudes towards a brand, advertising model and consumer relationship, an alignment of the advertising message with its intended consumers, and visual image of advertisements have a positive effect on consumers' brand experience. And the brand experience contributes to a distinctive attitude towards the brand and differentiates the brand from others. Ismail (2011) conducted an empirical study to examine the antecedents and consequences of consumer experience. The results show that services cape, core service, and word of mouth have a positive impact on brand experience and it affects brand loyalty.

All this shows that consumers put an importance on their directly and indirectly evoked experience with a brand by brand image, familiar models in advertisements, store image, friendly staff, and convenient ordering system. Thus, the brand experience providers, provided by companies, including brand communication means, visual-and-verbal identity elements, product design, co-branding, stores' environment, electronic media, and human element, can be utilized as marketing stimuli to evoke consumers' experience. 


\subsection{Brand Experience}

Experience refers to a personal response brought by observing a real or imaginary situation or by actually undergoing the situation. Those responses are created by a combination of every physical and emotional reactions that it could be shown either positively or negatively, and mostly induced not automatically made ( $\mathrm{O}^{\prime}$ Sullivan \& Spangler, 1998). Schmitt (1999) who systemized importance of experience in marketing levels, said human experience can be departmentalized in various forms, and each form have intrinsic structuralizing process, and he also defined experimental marketing as strategic experiential modules after restructuring it with marketing strategy and purpose.

The form of experience marketing is not entirely innovative marketing strategy. It is following tracks of traditional marketing, and is classified into one big concept of experience marketing and logically categorized (Schmitt, 2009). Experience marketing mainly focused on behavioral response caused by a product's technical attribute, whereas it is not on overall experience aroused by brand itself. Brand experience can be defined as comprehensive impression left on consumers through overall experience with specific brand (Klaus \& Maklan, 2007). Such brand experience plays central role in a corporation's will in creating industry top brand (Payne, Storbacka, Frow, \& Knox, 2009).

Recently, regarding brand experience, Brakus et al. (2009) and Zarantonello et al. (2007) conceptualized brand experience and classified it according to types. In their studies, brand experience was defined as consumers' intrinsic, subjective and behavioral response toward a specific brand. To acquire these kinds of consumer responses, there needs means to trigger people to have the brand experience, and the means can be roughly divided into brand identity factors and brand communication factors. Brand identity factors include color, shape, font, design, slogan, mascot, character, brand name, and logo. Brand communication factors include TV commercial, package, website, brochure and store atmosphere.

Meanwhile, there are four brand experience types for brand's overall experience to be completed: sensory, affective, behavioral, and intellectual experience (Brakus et al., 2009; Zarantonello et al., 2007). First, brand's sensory experience is response of sensory organs such as sight, hearing, and tactile. Such brand sensory experience may be considered as consumers' response on aesthetic and may produce overall impression like brand personality (Hagtvedt \& Patrick, 2008; Orth \& Malkewitz, 2008). Second, brand's affective experience is consumers' emotional response triggered by the brand. It means developing brand asset by deriving special feeling from consumers of the brand is the goal of affective experience. Therefore, brand's affective experience might be continued to consumer=brand emotional ties (Thomson, MacInnis, \& Park, 2005). Third, brand's behavioral experience is behavioral and physical responses which consumers experience through brand that it is motivated by their desire to present their lifestyle and express themselves. This is beyond the experience of sensory and affective that it is often detected in interaction among customers. Lastly, brand's intellectual experience is consumers' cognitive response towards brand. Brand's intellectual experience is composed of divergent thinking which induces flexible and associative inference, and convergent thought leading analytic inference (Schmitt, 2003). When these four brand experiences are in harmony, overall brand experience could be consummated and it could be foundation of forming consumer-brand relationship (Brakus et al., 2009; Schmitt, 2003).

Based on brand experience defined and classified by Brakus et al. (2009), many studies confirmed the relationship between brand experience and consumer's emotional response, faith, and behavior toward brand (Brakus et al., 2009; Lee \& Kang, 2012; Iglesias, Singh \& Batista-Foguet, 2011; Morgan-Thomas \& Veloutsou, 2011). Brakus et al. (2009) stated that brand experience not only directly influence brand identity, satisfaction and loyalty but indirectly influence brand loyalty through brand characteristics and brand satisfaction. By confirming direct and indirect relationship between brand experience and brand loyalty, Iglesias et al. (2011) stated brand experience influence brand loyalty as consumer is affectionately immersed to brand. Morgan-Thomas \& Veloutsou (2011) claimed consumers' online brand experience build online brand asset as consumers are satisfied and have behavior intention. Lee \& Kang (2012), regarding brand attachment as trust and commitment towards brand, observed relationship between emotional and behavioral brand experience and found that emotional brand experience positively influenced both brand trust and commitment but behavioral brand experience only influenced the latter one. Ishida \& Taylor (2012) observed the consistency among retailers as well as the relationship between consumers' satisfaction and loyalty towards a retailer brand and confirmed that consistency of brand experience 
among retailers played a significant role in brand satisfaction and loyalty. Zarantonello \& Schmitt (2013) looked at how event marketing contributes to brand asset and stated that brand experience influence how consumers evaluate brand asset before and after holding event marketing.

\section{RESEARCH FRAMEWORK AND HYPOTHESIS}

\subsection{Research Framework}

Companies' brand experience providers - brand communication means, visual-and-verbal identity element, product design, co-branding, store's physical environment, electronic media, and human elements, etc. - can be utilized as strategic marketing stimuli to evoke consumers' experience with a brand (Brakus et al., 2009; Schmitt, 1999). Thus, consumers' brand experience can be triggered by a various set of corporate marketing actions.

Therefore, this present research distinguishes brand experience providers of cosmetic companies that include three elements: Brand identity elements of cosmetic brand shops (feminine and environmental-friendly brand identity); Marketing mix elements (level of iconic product, level of steady-seller product, reasonable pricing, convenience of location, quality of additional service); Cosmetic brand store elements (effective product assortment, atmosphere of a store, availability of testers, proficiency of consultants). This paper aims to explore these elements and the effect of brand experience provider on all brand experience dimensions; sensory, affective, intellectual, and behavioral experience (Figure 1). 
Figure 1. Research Framework
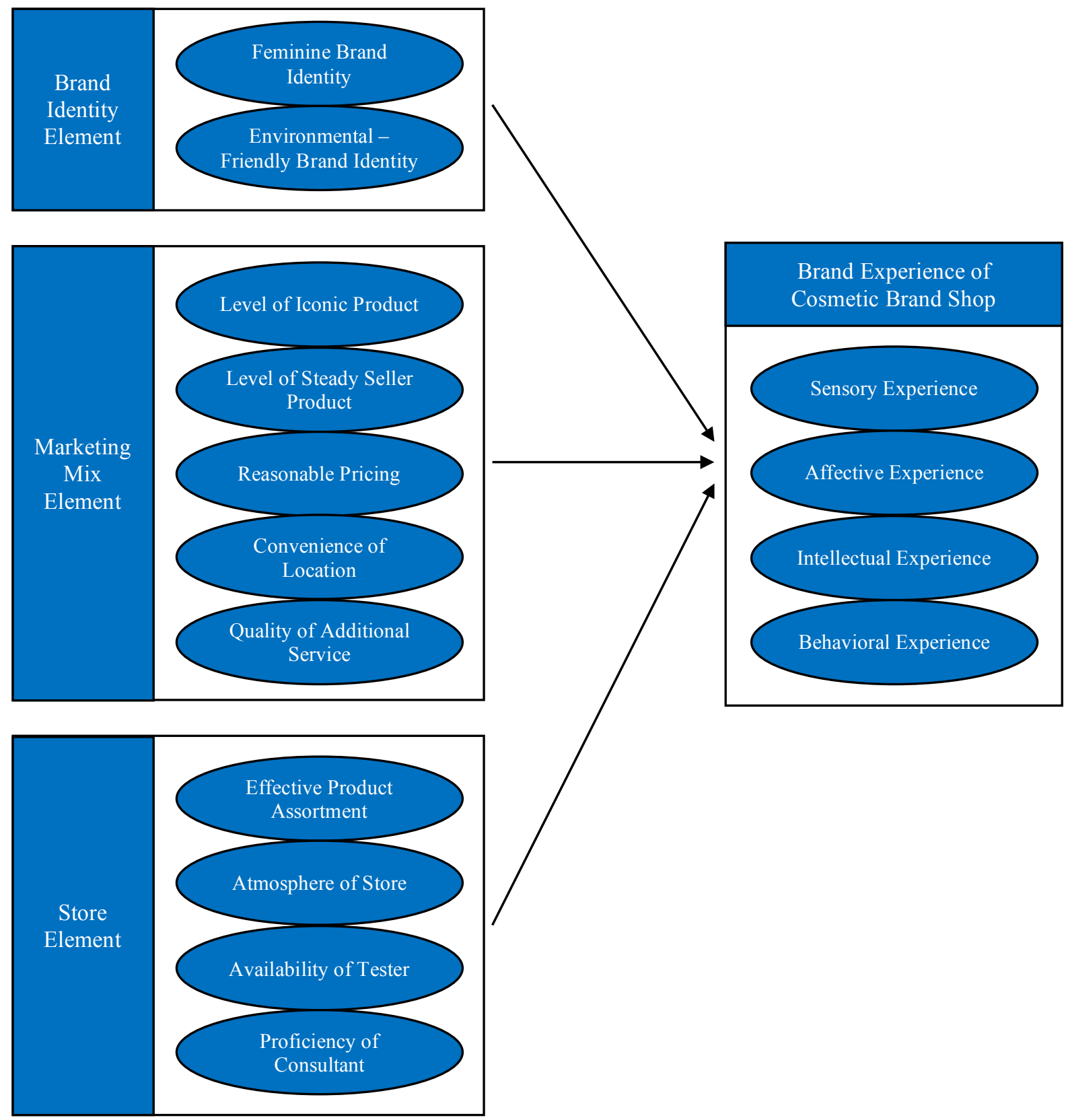

\subsection{Hypotheses}

3.2.1 The Relationship Between Feminine and Environmental-Friendly Brand Identity of the Cosmetic Brand Shops and Brand Experience

The function and role of company's brand identity is to raise brand awareness, strengthen differentiation, and give brand-related sensations that last long in the memory (Kapferer, 1997). This perception of the company's brand identity can affect brand experience (Verhoef et al., 2009). Brand identity is the vision, mission, value, and visual and verbal association with a brand which shows what the brand represents and involves brand's promise to clients 
(Aaker, 1996). Among those visual and verbal elements of brand identity, there are logo, symbol, slogan, packaging, and colors. They must support brand identity in a coherent and distinct way (Aaker, 1996). That indicates that visual and verbal identity elements of a brand evoke brand experience, the key factor to nurture consumer attitude and stimulate consumer associations (Schmitt, 1999).

Regarding Schmitt (1999), visual and verbal identities affect consumers' brand experience. They are symbol, logo, and slogan among many others. Fitzsimons, Chartrand, \& Fitzsimons (2008) indicated that if consumers had positive brand recognition before the purchase at the brand's retail store, they tend to have a favorable evaluation of a brand while experiencing the brand directly and indirectly. It suggests that consumer recognition of brand identity has a positive relationship with brand experience (Ofir \& Simonson, 2007). Brakus et al. (2009) stated the key factors that affect sensory, affective, intellectual, and behavioral brad experience can be categorized into brand identity elements and brand communication elements. Brand identity elements are colors, shapes, typefaces, designs, slogans, mascots, brand characters, brand name, and logo and brand communication elements are TV advertisements, packaging, website brochure, and store's atmosphere (Brakus et al., 2009). Along with the findings proposed by previous studies mentioned above, cosmetic brand shops communicate their specific brand identity with consumers through store's internal and external factors. Because they are cosmetic companies, cosmetic brand shops highlight their feminine and environmental-friendly identity. Thus, we set up a hypothesis as follows:

Hypothesis 1: Feminine brand identity of cosmetic brand shops has a positive influence on brand experience.

Hypothesis 2: Environmental-friendly brand identity of cosmetic brand shops affects brand experience positively.

\subsubsection{The Relationship Between the Level of Iconic and Steady-Seller Product of Cosmetic Brand Shops and Band Experience}

If product value successfully lived up to consumer's expectations, consumers can have a favorable evaluation and even feel positive emotion while purchasing. That is, products that consumers positively recognize can affect consumer's emotional and perceptional experience. Product shapes and quality can lead consumers to positive brand experience as brand experience providers that include product design, packaging, product assortment, point-ofpurchase advertisements, and brand characters (Schmitt, 1999). Thus, product with distinctive and high quality can deliver a pleasant shopping experience (Jones, 1999).

Knutson \& Beck (2003) stated that considering the fact that services are immediately delivered to consumers, consumers immediately have a positive experience with a quality service. Grewal et al. (2009) pointed out product, pricing, promotions, supply chain management, and store location as key factors that provide impeccable experience and suggested that the positive experience from these factors induce clients' satisfaction and revisit and add more value for the company. In particular, high quality products are a main factor that affects consumers' positive experience with a retailer of the products.

Moreover, Davis (2012) suggested that spacious store environment, multifunctional and comfortable fixture of a store, friendly staff, high quality products, and pricing can lead the consumer in the pleasant shopping experience. And Davis (2012) highlighted that high quality products at retail shops are the most important factor to induce positive consumer experience. Particularly for cosmetics, they are directly applied to consumer's body so that cosmetic companies focus more on product quality management. As part of an effort, cosmetic companies have distinctive iconic products and steady-seller products; Iconic products provide value to consumers more than expected and generate explosive demand and, in turn, companies can make a big profit; Steady-seller products have a high market share, are very popular, generate explosive profits, and attract the attention of the public through distinctive idea and quality. Thus, we set up a hypothesis as follows:

Hypothesis 3: The level of iconic product in cosmetic brand store has a positive influence on brand experience.

Hypothesis 4: The level of steady-seller product in cosmetic brand store affects brand experience positively. 


\subsubsection{The Relationship Between Reasonable Pricing of Cosmetic Brand Shops and Brand Experience}

Price is very important clue that consumers evaluate brand's product and services. Consumers use price as a means of creating experience with a relevant brand (Ismail, 2011). No matter how best quality the product is, the product can never deliver good experience to the customer, if consumers perceive the price of a product is not reasonable (Cox, Cox, \& Anderson, 2005). In other words, reasonable price of a product can affect consumer's positive brand experience (Terblanche \& Boshoff, 2004). Grewal et al. (2009) showed that the important elements that retailers can provide the best experience to consumers are promotions, pricing, product assortment, supply chain management, and store location. This positive experience with the retailer relates to consumers' satisfaction, revisit, and added value to the company. Verhoef et al. (2009) suggested that the store elements that affect positive consumer experience are social environment, service interaction, store's atmosphere, product assortment, pricing, and consumer's experience with other retailers, product lines in stores, and previous consumer experience. Thus, we set up a hypothesis as follows:

Hypothesis 5: Reasonable price in cosmetic brand shop have a positive influence on brand experience.

\subsubsection{The Relationship Between Convenient Location of Cosmetic Brand Shop and Brand Experience}

Stores located in convenient area where consumers can easily find and conveniently visit can provide positive shopping experience to consumers. In other words, if a store were located in an area that has a large floating population, and if consumers found a store easy to visit and convenient to use, the stores can affect sensory and affective experience during the purchasing (Babin \& Darden, 1995). Among marketing mix elements, retail strategies such as accessibility, convenience, and enlargement of a store contribute to create consumers' positive store experience.

Hart, Farrell, Stachow, Reed and Cagogan (2007) looked into the factors that can affect clients' shopping experience and found that the accessibility of a store including its location with a large floating population and convenient parking facility has a significant influence on consumers' shopping experience. Grewal et al. (2009) stated that among the elements that can contribute to the greatest consumer experience with a company, a prime location of a store affects not only consumer's positive brand experience, but also their satisfaction, revisit, and increase companies' profits. Thus, we set up a hypothesis as follows:

Hypothesis 6: A convenient location of a store affects brand experience.

\subsubsection{The Relationship Between the Quality of Cosmetic Brand Shop's Additional Service and Brand Experience}

For service are the intangible element, the demand and supply of service simultaneously occurring so that it can give a direct experience to consumers (Ismail, 2011). Additional services like opening and closing hours of shops, fresh water and coffee, parking facility, and customer complain handling procedure can affect clients' favorable experience with stores (Backstrom \& Johansson, 2006). In addition, stores' service system, policies, and complain handling procedure, and other additional services in stores can induce positive consumer experience of the relevant store (Davis, 2012).

Page \& Connell (2006) showed that peripheral service of hotel brands is a key element that creates travelers' extraordinary experience. Ismail (2011) conducted an empirical survey of British resort hotel brands on precedence and consequence factors contributing to brand experience. The results suggest that services cape, peripheral service, and word-of-mouth positively influence brand experience, contributing to brand loyalty. Davis (2012) conducted indepth interview to examine stores' environmental factors that affect northwest Chinese consumers' shopping experience. It confirmed that store's atmosphere, store design, social environment, store's peripheral service, and product assortment influence Chinese consumers' shopping experience. Particularly for cosmetic brand shops offer peripheral services such as store's service system, policy, and complain handling. That's not all. They also provide scalp, nail, eye brow, and hand therapies, and other additional services. Thus, we set up a hypothesis as follows:

Hypothesis 7: The quality of additional service of cosmetic brand shops affects brand experience. 


\subsubsection{The Relationship Between Product Assortment of Cosmetic Brand Shop and Brand Experience}

Store's physical environment includes tangible elements that can be meticulously planned by a company. They are lights, colors, symbols, merchandise assortment and disposition, store fixture, and cleanliness (Baker, 1987). Consumers can have a objective experience of store's physical environment that can be categorized into ambient condition, spatial layout and functionality, signs, symbols, and artifacts (Bitner, 19982). Indeed, store's physical environment plays a key role in consumers' experience with a brand shop through interactions (Verhoef et al., 2009).

In terms of stores' product assortment and disposition, if it is coherent that consumers can perceive, it can give product information directly and inspire positive consumer experience of a store by enhancing the store's credibility (Bagdare, 2013). And if store's product assortment and disposition were coherent and provided more freedom for consumer's movement, consumers can have a favorable brand experience (Jones, 1999). Backstrom \& Johansson (2006) also pointed out store's atmosphere, layout, service, and product assortment as the important factors that can affect consumers' experience of a company. And they underscore coherent merchandise assortment and disposition is very important because it provides freedom for consumer's movement. Verhoef et al. (2009) defined consumers' brand experience as cognitive, affective, emotional, social, and behavioral responses that consumers gain during searching, purchasing, consuming products of a brand and even getting the after-sales service. And they also put an importance on coherent product assortment and disposition in stores among other factors. Cosmetic brand shops take the in-store movement of customers into consideration and help them approach and use testers by displaying products according to categories and brand lines (TENX, 2012). Thus, we set up a hypothesis as follows:

Hypothesis 8: Efficient store assortment of cosmetic brand shops positively affects brand experience.

\subsubsection{The Relationship Between the Atmosphere of Cosmetic Brand Shop and Brand Experience}

Consumers' shopping experience is strictly connected to the atmosphere of a store (Kerin, Jin, \& Howard, 1992). The atmosphere of a store means colors, lights, sound, fixtures and other store's physical environment that is designed to stimulate consumers' sensory and affective responses. Store's color, music, temperatures, volumes, scents, and decorations create the atmosphere of a store and can positively affect consumer's affective experience. In other words, favorable store's atmosphere and provide the pleasant, leading to amusing shopping experience (Sullivan \& Adcock, 2002).

Soars (2009) stated that silent, comfortable, and active atmosphere of retail stores affects consumers' positive experience of a store and purchasing decision. To this end, stores' lights, music, scents, and other elements of stores' atmosphere should be under control. Bagdare (2013) suggested that the four elements that affect clients' positive experience of a store are stores' atmosphere, convenience, staff, and relationship-centered culture, and conducted an empirical study on the relationship between the four elements and consumer experience. The results show that all of the four elements affect consumer experience of a store positively and the atmosphere of a store is the most influential element. Thus, we set up a hypothesis as follows:

Hypothesis 9: The atmosphere of cosmetic brand shops has a positive influence on brand experience.

\subsubsection{The Relationship Between the Availability of Cosmetic Testers in Cosmetic Brand Shop and Brand Experience}

By seeing and touching, consumers acquire verbal and non-verbal information that can play an important role in their positive brand experience and purchasing behavior (Schmitt, 1999). It indicates that consumers' full experience of a brand, created by directly trying out products of the bran, is a key factor that can affect the evaluation of a product and a purchasing decision. Thus, self-service technology that consumers can try out products inside a retail store and use self-testing equipment to check themselves can positively result in reduction of perceived waiting time, consumer satisfaction with a retail store, and store loyalty (Holloway \& Beatty, 2008).

Schmitt (2003) categorized the elements of brand experience into store's exterior and atmosphere, communication, and product experience inside a store. The exterior and atmosphere of a store are related to visual identity of a brand 
including logo, sign, store design, fun and informative service, and personnel who needs to lead the consumers. Schmitt explained that product experience inside a store is a process while consumers perceive products' functional and aesthetic characteristics and consume the product. And the product experience plays a critical role in building up brand experience. Verhoef et al. (2009) suggested that self-service technology in stores affects consumer's positive experience of a retail store. Cosmetic brand shops always provide opportunities for customers to have a direct experience with their brands by always displaying testers from skin care products to cleansers, and self-examining skin care equipment. Thus, we set up a hypothesis as follows:

Hypothesis 10: The availability of cosmetic testers of cosmetic brand shops affects brand experience positively.

\subsubsection{The Relationship Between the Proficiency of a Consultant in Stores and Brand Experience}

Human resources have the highest impact as the brand experience providers. They encompass salespeople, Sales Liaison Staff, after sales manager, and other employees related to a brand. Among them, staff in store is the key to create consumers' brand experience (De Chematony \& McDonald, 1998). Consumers can have entertaining store experiences especially when they realize the staff has the ability to provide extraordinary service experience (Jones, 1999). That indicates that reliable and professional store staff is the determinant of creating consumers' amusing shopping experience (Kelley \& Hoffman, 1997).

Schmitt (1999) highlighted store staff's role that can create consumer experience because consumer's simple transaction in store can be transformed into an overall satisfied experience by store staff. According to Hart et al. (2007), the proficiency and friendly attitude of shop workers is the most influential factor to create positive consumer experience. Jain \& Bagdare (2009) found that store employers contribute to consumer's satisfaction and positive experience, and other store's accomplishments. Bagdare (2013) carried out an empirical analysis of the consumer experience and the four influential factors - store's atmosphere, convenience, staff, and relationshiporiented culture, and found out that the four factors all, particularly for store's staff, have a positive imp ace on consumer experience. In cosmetic brand shop, store staffs are called consultants and they are mostly young and well-trained about the brand products. The role of consultants in cosmetic brand shops is to provide various information and help clients have a deeper brand knowledge and experience by offering tailored skin consultation according to skin types, explaining the pros and cons of a product, and sharing their own experience of using the product, and recommending other products that can maximize the effects of products. Thus, we set up a hypothesis as follows:

Hypothesis 11: The proficiency of consultants in cosmetic brand shops positively affects brand experience.

\section{RESEARCH METHOD}

\subsection{Data Collection and Research Methods}

Focusing on Korean cosmetics brand shop, this study is conducted to find the relationship between consumer experiences in general affect the formation of brand love. Before conducting a survey, the researcher conducted a pre-survey, personally meeting 30 Korean consumers with experience of using Korean cosmetics brand shop brands including 'Etude House,' 'Aritaum,' 'MiSSHA,' 'Innisfree,' 'Tony Moly,' 'Beauty Credit,' 'The Face Shop,' 'Nature Republic,' and 'Skin Food,' to confirm the clarity of survey questions set based on previous citations. As the pre-survey confirmed the validity of structured question, the actual survey was conducted afterwards.

The research was conducted for 10 days from February 32014 to February 12 2014. Five surveyors including the researcher visited cosmetic brand shops and explained the purpose of research before conducting the survey. The target consumer was 343 university students and office workers having experience of using cosmetics brand and the research team could collect 308 responses. After excluding 13 responses that are poorly made including having question omission or unable to identify, a total of 295 responses (utilization rate: 96\%) were analyzed. The responses were empirically analyzed via statistics program SPSS ver. 15.0 and AMOS ver. 7.0. Meanwhile, the variables used in this research were measured in multiple scales in the form of point 7 Likert. The following is the details of the variables. 


\subsection{Variable Measurements}

\subsubsection{Brand Experience of Cosmetics Brand Shop}

The research defined brand experience of cosmetics brand shop as subjective and behavioral response made in the process of purchasing and consuming the cosmetics shop brand. Brakus et al. (2009) categorized brand experience of cosmetics brand shop as sensory, affective, intellectual and behavioral brand experience. Therefore, in this study, brand experience is defined as consumers' subjective and behavioral response caused in the process of purchasing and consuming in cosmetic brand shop. To measure it, this study divided brand experience into four subordinate concepts used in Brakus et al. (2009)'s study and set four items to measure sensory experience, four items for sensory experience, four items for affective experience, four items for intellectual experience, and three items for behavioral experience.

\subsubsection{Feministic Brand Identity of Cosmetics Brand Shop}

Brand identity is a tendency, goal, and meaning of brand and is a series of association related to a visually and linguistically expressed brand (Aaker, 1996). Therefore, this study defined feminine brand identity of cosmetics brand shop as the level of understanding consumers have towards feministic image in visual and linguistic elements which express brand identity of cosmetics brand shop, including color, shape, brand calligraphy, brand name, logo, slogan, interior and display. To measure the level of feminine brand identity, this study modified and used eight items based on studies conducted by Brakus et al. (2009) and Schmitt (1999).

\subsubsection{Environmental-Friendly Brand Identity of Cosmetics Brand Shop}

Brand identity is a tendency, goal, and meaning of brand and is a series of association related to a visually and linguistically expressed brand (Aaker, 1996). Therefore, this study defined environmental-friendly brand identity of cosmetics brand shop as the level of understanding consumers have towards eco-friendly image in visual and linguistic elements which express brand identity of cosmetics brand shop, including color, shape, brand calligraphy, brand name, logo, slogan, interior and display. To measure the level of environmental-friendly brand identity, this study modified and used eight items based on studies conducted by Brakus et al. (2009) and Schmitt (1999).

\subsubsection{Level of Iconic Product of Cosmetics Brand Shop}

Iconic product is considered to bear high profit by generating a blaze of demand by providing value to consumers beyond their expectation (TNEX, 2012). Therefore, this study defined level of iconic product of cosmetics brand shop as the capability of brand shops providing consumers with products that generated a blaze of demand by providing value beyond consumers' expectation such as excellence in function, design, and wrapping, high performance per price, and trend-setter feature. To measure the level of iconic product, this study modified and used five items based on studies conducted by Bagdare (2013) and Grewal et al. (2009).

\subsubsection{Level of Steady-Seller Product of Cosmetics Brand Shop}

Steady-seller product is defined as an item highly recognized by consumers for its excellent idea and quality, enjoying large market share, continued popularity among consumers and explosive sales growth (TNEX, 2012). Therefore, this study defined level of steady-seller product of cosmetics brand shop as the capability of brand shops providing consumers products with high quality compared to price, enjoying large market share and generating continuous popularity among consumers by constantly improving design, function, quality, and size. To measure the level of steady seller product, this study modified and used five items based on studies conducted by Bagdare (2013) and Grewal et al. (2009).

\subsubsection{Reasonable Price of Cosmetic Brand Shop}

Reasonable price is the level of rationality consumers have towards price of an excellent item (Cox et al., 2005). Therefore, this study defined reasonable price of cosmetics brand shop as the recognition of consumers that the price 
is rational, ideal, and economic so that it is not burdensome to purchase. To measure the reasonable price, this study modified and used four items based on studies conducted by Grewal et al. (2009) and Verhoef et al. (2009).

\subsubsection{Location Convenience of Cosmetics Brand Shop}

Location convenience is the convenience consumers feel when finding and visiting a store (Babin and Darden, 1995). Therefore, this study defined location convenience of cosmetics brand shop as the level of convenience consumers feel when finding and visiting store as it is located in main commercial district in a large scale. To measure the convenience, this study modified and used four items based on studies conducted by Grewal et al. (2009) and Hart et al. (2007).

\subsubsection{Additional Service Quality of Cosmetics Brand Shop}

In-store additional service includes services in regards to store service system, policy, complaint process, and strengthened benefits to consumers (Davis, 2012). Therefore, this study defined additional service quality of cosmetics brand shop as the level of evaluating services including skin, nail, eye brow and hand therapy care and other services as excellent by consumers who purchased items in cosmetics brand shop stores. To measure the additional service quality level, this study modified and used four items based on studies conducted by Davis (2012) and Ismail (2011).

\subsubsection{Effective Product Assortment of Cosmetics Brand Shop}

Product assortment is defined as the composition of store that includes products articulately lined up to help consumer intuit in-store products and provide product information directly to consumers (Bagdare, 2013). Therefore, this study defined effective product assortment of cosmetics brand shop as the level of efficiency in space arrangement consumers feel when finding and testing item. To measure the effective product assortment, this study modified and used three items based on studies conducted by Grewal et al. (2009) and Verhoef et al. (2009).

\subsubsection{Store Atmosphere of Cosmetics Brand Shop}

Store atmosphere is a physical environment of brand store designed to stimulate perceptual and emotional response by color, light, sound, and furniture (Kotler, 1973). Therefore, this study defined store atmosphere of cosmetics brand shop as a store condition with moderate temperature, bright light, fresh air, pleasant music, and uncrowded space. To measure the atmosphere of store, this study modified and used five items based on studies conducted by Donovan and Rossiter (1982) and Bagdare (2013).

\subsubsection{Availability of Tester of Cosmetics Brand Shop}

Product tester is an action consumers test in-store product or use devices to self-diagnose one's condition (Holloway and Beatty, 2008). Therefore, this study defined availability of tester of cosmetics brand shop as a condition brand shop prepared appropriate information about product test and a device for self-diagnose as well as a condition consumers feel comfortable with testing items and conducting makeup trial run. To measure the availability of tester, this study modified and used four items based on studies conducted by Schmitt (2003) and Verhoef et al. (2009).

\subsubsection{Proficiency of Consultants of Cosmetics Brand Shop}

In-store consultants are human resources enable to provide credible service and information on in-store products with professionalism to consumers (De Chernatony and McDonald, 1998). Therefore, this study defined proficiency of consultants of cosmetics brand shop as the capability of consultants providing information including elements and effectiveness of product, makeup trend and skin care advices to consumers with professionalism. To measure the proficiency of consultant, this study modified and used five items based on studies conducted by Ismail (2011) and Verhoef et al. (2009). 


\section{RESULTS}

\subsection{Characteristics of Sample}

Comprehensive characteristics of the sample, including general characteristics, are shown in the following Table 1.

Table 1. Characteristics of Sample

\begin{tabular}{|c|c|c|c|}
\hline & Content & Num. & $\%$ \\
\hline \multirow{2}{*}{ Gender } & Male & 97 & 32.8 \\
\hline & Female & 198 & 67.2 \\
\hline \multirow{5}{*}{ Age } & $20 \sim 29$ & 101 & 34.0 \\
\hline & $20 \sim 29$ & 101 & 34.0 \\
\hline & $30 \sim 39$ & 87 & 29.5 \\
\hline & $40 \sim 49$ & 80 & 27.1 \\
\hline & 50 and more & 27 & 9.4 \\
\hline \multirow{6}{*}{ Job } & Specialized Work & 43 & 14.5 \\
\hline & Business & 24 & 8.1 \\
\hline & Office Work & 117 & 39.7 \\
\hline & Student & 50 & 16.9 \\
\hline & Housewife & 29 & 9.8 \\
\hline & Others & 32 & 11.0 \\
\hline \multirow{5}{*}{ Education Background } & High School & 23 & 7.8 \\
\hline & Junior College & 32 & 10.8 \\
\hline & University & 69 & 23.5 \\
\hline & Graduate School & 121 & 41.0 \\
\hline & Others & 50 & 16.9 \\
\hline \multirow{5}{*}{ Average Monthly Income } & Less 100 mil won & 46 & 15.6 \\
\hline & 100 200 mil won & 50 & 16.9 \\
\hline & $200 \sim 300$ mil won & 72 & 24.4 \\
\hline & 300 400 mil won & 67 & 22.7 \\
\hline & More 500 mil won & 60 & 20.4 \\
\hline \multirow{5}{*}{ Average Monthly Utilization Cost } & Less 5 mil won & 72 & 24.4 \\
\hline & 5 10 mil won & 85 & 28.8 \\
\hline & 11 20 mil won & 62 & 21.0 \\
\hline & 21 30 mil won & 41 & 13.8 \\
\hline & More 30 mil won & 35 & 12.0 \\
\hline \multirow{10}{*}{ Cosmetic Brand Shop } & Etude House & 26 & 8.8 \\
\hline & Aritaum & 63 & 21.3 \\
\hline & Missha & 42 & 14.2 \\
\hline & Innisfree & 60 & 20.3 \\
\hline & Tony Moly & 15 & 5.1 \\
\hline & Beauty Credit & 8 & 2.7 \\
\hline & The Face Shop & 31 & 10.5 \\
\hline & Nature Republic & 13 & 4.4 \\
\hline & Skin Food & 21 & 7.1 \\
\hline & Others & 16 & 5.6 \\
\hline Sum & & 295 & 100 \\
\hline
\end{tabular}

\subsection{Reliability and Validity Analysis}

\subsubsection{Exploratory Factor Analysis}

As indicated in Table 2, we conducted the exploratory factor analysis and calculated Cronbach's alpha coefficient, to confirm unidimensionality of operationalized measures, which consist of different concepts. The items designed 
in the main survey were grouped individually, as we planned, thus, total of five dimensional factors were deducted after applying eigenvalue greater than one. Of the measurement items of four brand experience dimensions, still, three cross-loading items were found and eventually were deleted. In addition, Cronbach's alpha coefficient was calculated to verify internal consistency and the result shows most of demonstrated coefficients were greater than 0.6 .

Table 2. Exploratory Factor Analysis

\begin{tabular}{|c|c|c|c|c|c|}
\hline \multicolumn{2}{|c|}{ Measurement } & Measurement Item & $\begin{array}{c}\text { Factor } \\
\text { Loading }\end{array}$ & $\begin{array}{c}\text { Eigenvalue } \\
(\%)\end{array}$ & Cronbach's $\alpha$ \\
\hline \multirow{12}{*}{$\begin{array}{l}\text { Brand } \\
\text { Experience } \\
\text { of } \\
\text { Cosmetic } \\
\text { Brand } \\
\text { Shop }\end{array}$} & \multirow{3}{*}{$\begin{array}{l}\text { Sensory } \\
\text { Experience }\end{array}$} & $\begin{array}{l}\text { Cosmetic brand shop left a strong impression on my } \\
\text { sense. }\end{array}$ & .797 & \multirow{3}{*}{$\begin{array}{l}1.745 \\
(3.082)\end{array}$} & \multirow{3}{*}{.808} \\
\hline & & Cosmetic brand shop makes my sense interesting. & .750 & & \\
\hline & & Cosmetic brand shop excites my sense. & .746 & & \\
\hline & \multirow{3}{*}{$\begin{array}{l}\text { Affective } \\
\text { Experience }\end{array}$} & I felt special emotion about Cosmetic brand shop. & .798 & \multirow{3}{*}{$\begin{array}{c}1.892 \\
(3.319)\end{array}$} & \multirow{3}{*}{.817} \\
\hline & & I felt happiness about Cosmetic brand shop & .762 & & \\
\hline & & I felt satisfaction about Cosmetic brand shop & .749 & & \\
\hline & \multirow{4}{*}{$\begin{array}{l}\text { Intellectual } \\
\text { Experience }\end{array}$} & Cosmetic brand shop makes me think a lot of thought. & .783 & \multirow{4}{*}{$\begin{array}{c}1.741 \\
(2.892)\end{array}$} & \multirow{4}{*}{.825} \\
\hline & & Cosmetic brand shop excites my curiosity. & .768 & & \\
\hline & & I am aware of new fact about Cosmetic brand shop & .742 & & \\
\hline & & I have special thinking about Cosmetic brand shop & .731 & & \\
\hline & \multirow{2}{*}{$\begin{array}{l}\text { Behavioral } \\
\text { Experience }\end{array}$} & Cosmetic brand shop induces my physical action. & .785 & \multirow[b]{2}{*}{$\begin{array}{l}1.519 \\
(2.679)\end{array}$} & \multirow[b]{2}{*}{.809} \\
\hline & & $\begin{array}{l}\text { I actively participate in the event of Cosmetic brand } \\
\text { shop }\end{array}$ & .764 & & \\
\hline \multirow{8}{*}{\multicolumn{2}{|c|}{$\begin{array}{l}\text { Feminine Brand Identity } \\
\text { of Cosmetic Brand Shop }\end{array}$}} & $\begin{array}{l}\text { The color of Cosmetic brand shop reminds me of } \\
\text { Feminine image. }\end{array}$ & .809 & \multirow{8}{*}{$\begin{array}{c}3.617 \\
(6.248)\end{array}$} & \multirow{8}{*}{.824} \\
\hline & & $\begin{array}{l}\text { The form of Cosmetic brand shop reminds me of } \\
\text { Feminine image. }\end{array}$ & .786 & & \\
\hline & & $\begin{array}{l}\text { The font of Cosmetic brand shop reminds me of } \\
\text { Feminine image. }\end{array}$ & .763 & & \\
\hline & & $\begin{array}{l}\text { The brand name of Cosmetic brand shop reminds me of } \\
\text { Feminine image. }\end{array}$ & .738 & & \\
\hline & & $\begin{array}{l}\text { I think the logo of Cosmetic brand shop represents well } \\
\text { Feminine image. }\end{array}$ & .716 & & \\
\hline & & $\begin{array}{l}\text { I think the slogan of Cosmetic brand shop shows well } \\
\text { Feminine image. }\end{array}$ & .701 & & \\
\hline & & $\begin{array}{l}\text { I think the interior of Cosmetic brand shop expresses } \\
\text { well Feminine image. }\end{array}$ & .693 & & \\
\hline & & $\begin{array}{l}\text { I think the display of Cosmetic brand shop expresses } \\
\text { well Feminine image. }\end{array}$ & 672 & & \\
\hline \multirow{8}{*}{\multicolumn{2}{|c|}{$\begin{array}{l}\text { Environmental-Friendly } \\
\text { Brand Identity of } \\
\text { Cosmetic Brand Shop }\end{array}$}} & $\begin{array}{l}\text { The color of Cosmetic brand shop reminds me of } \\
\text { environmental-friendly image. }\end{array}$ & .824 & \multirow{8}{*}{$\begin{array}{c}3.041 \\
(5.532)\end{array}$} & \multirow{8}{*}{.803} \\
\hline & & $\begin{array}{l}\text { The form of Cosmetic brand shop reminds me of } \\
\text { environmental-friendly image. }\end{array}$ & .812 & & \\
\hline & & $\begin{array}{l}\text { The font of Cosmetic brand shop reminds me of } \\
\text { environmental-friendly image. }\end{array}$ & .791 & & \\
\hline & & $\begin{array}{l}\text { The brand name of Cosmetic brand shop reminds me of } \\
\text { environmental-friendly image. }\end{array}$ & .765 & & \\
\hline & & $\begin{array}{l}\text { I think the logo of Cosmetic brand shop represents well } \\
\text { environmental-friendly image. }\end{array}$ & .763 & & \\
\hline & & $\begin{array}{l}\text { I think the slogan of Cosmetic brand shop shows well } \\
\text { environmental-friendly image. }\end{array}$ & .757 & & \\
\hline & & $\begin{array}{l}\text { I think the interior of Cosmetic brand shop expresses } \\
\text { well environmental-friendly image. }\end{array}$ & .744 & & \\
\hline & & $\begin{array}{l}\text { I think the display of Cosmetic brand shop expresses } \\
\text { well environmental-friendly image. }\end{array}$ & .728 & & \\
\hline
\end{tabular}

(Table 2 continued on next page) 
(Table 2 continued)

\begin{tabular}{|c|c|c|c|c|}
\hline Measurement & Measurement Item & $\begin{array}{c}\text { Factor } \\
\text { Loading }\end{array}$ & $\begin{array}{c}\text { Eigenvalue } \\
(\%)\end{array}$ & Cronbach's $\alpha$ \\
\hline \multirow{5}{*}{ Level of Iconic Product } & $\begin{array}{l}\text { Cosmetic brand shop supplies hit products of superior } \\
\text { functionality. }\end{array}$ & .824 & \multirow{5}{*}{$\begin{array}{c}3.745 \\
(6.305)\end{array}$} & \multirow{5}{*}{.829} \\
\hline & $\begin{array}{l}\text { Cosmetic brand shop supplies hit products of superior } \\
\text { functionality compared to the price. }\end{array}$ & .803 & & \\
\hline & $\begin{array}{l}\text { Cosmetic brand shop supplies hit products ahead of the } \\
\text { curve. }\end{array}$ & .782 & & \\
\hline & $\begin{array}{l}\text { Cosmetic brand shop supplies hit products of superior } \\
\text { design. }\end{array}$ & .761 & & \\
\hline & $\begin{array}{l}\text { Cosmetic brand shop supplies hit products of superior } \\
\text { packing. }\end{array}$ & .736 & & \\
\hline \multirow{5}{*}{$\begin{array}{l}\text { Level of Steady-Seller } \\
\text { Product }\end{array}$} & $\begin{array}{l}\text { Cosmetic brand shop supplies steady products superior } \\
\text { functionality compared to the price. }\end{array}$ & .814 & \multirow{5}{*}{$\begin{array}{c}3.092 \\
(5.731)\end{array}$} & \multirow{5}{*}{.805} \\
\hline & $\begin{array}{l}\text { Cosmetic brand shop supplies steady products of various } \\
\text { capacities. }\end{array}$ & .805 & & \\
\hline & $\begin{array}{l}\text { Cosmetic brand shop supplies steady products of } \\
\text { continually improved design. }\end{array}$ & .763 & & \\
\hline & $\begin{array}{l}\text { Cosmetic brand shop supplies steady products of } \\
\text { continually enhanced function. }\end{array}$ & .728 & & \\
\hline & $\begin{array}{l}\text { Cosmetic brand shop supplies steady products of } \\
\text { continually improved quality. }\end{array}$ & .709 & & \\
\hline \multirow{4}{*}{ Reasonability of Price } & The price of Cosmetic brand shop is reasonable. & .806 & \multirow{4}{*}{$\begin{array}{c}3.114 \\
(5.574)\end{array}$} & \multirow{4}{*}{.792} \\
\hline & $\begin{array}{l}\text { Cosmetic brand shop supplies ideal price for purchasing } \\
\text { products. }\end{array}$ & .762 & & \\
\hline & The price of Cosmetic brand shop is economical. & .738 & & \\
\hline & The price of Cosmetic brand shop is no burden on me. & .726 & & \\
\hline \multirow{4}{*}{$\begin{array}{l}\text { Convenience of Store } \\
\text { Location }\end{array}$} & $\begin{array}{l}\text { Cosmetic brand shop is situated in major business } \\
\text { district. }\end{array}$ & .809 & \multirow{4}{*}{$\begin{array}{c}3.615 \\
(6.258)\end{array}$} & \multirow{4}{*}{.818} \\
\hline & $\begin{array}{l}\text { Cosmetic brand shop is situated in the district with a } \\
\text { large floating population. }\end{array}$ & .793 & & \\
\hline & $\begin{array}{l}\text { Cosmetic brand shop is situated in convenience district } \\
\text { for use. }\end{array}$ & .752 & & \\
\hline & $\begin{array}{l}\text { Cosmetic brand shop is situated in convenience district } \\
\text { to find. }\end{array}$ & .731 & & \\
\hline \multirow{4}{*}{$\begin{array}{l}\text { Quality of Additional } \\
\text { Service }\end{array}$} & $\begin{array}{l}\text { Cosmetic brand shop has a high level of skin test } \\
\text { service. }\end{array}$ & .809 & \multirow{4}{*}{$\begin{array}{c}3.512 \\
(6.848)\end{array}$} & \multirow{4}{*}{.814} \\
\hline & $\begin{array}{l}\text { Cosmetic brand shop has a high level of nail care } \\
\text { service. }\end{array}$ & .768 & & \\
\hline & $\begin{array}{l}\text { Cosmetic brand shop has a high level of eyebrow care } \\
\text { service. }\end{array}$ & .738 & & \\
\hline & $\begin{array}{l}\text { Cosmetic brand shop has a high level of hand-therapy } \\
\text { care service. }\end{array}$ & .734 & & \\
\hline \multirow{3}{*}{$\begin{array}{l}\text { Efficiency of Product } \\
\text { Assortment }\end{array}$} & $\begin{array}{l}\text { Cosmetic brand shop has an efficient product } \\
\text { assortment. }\end{array}$ & .847 & \multirow{3}{*}{$\begin{array}{c}3.745 \\
(6.594)\end{array}$} & \multirow{3}{*}{.837} \\
\hline & $\begin{array}{l}\text { The product display of Cosmetic brand shop is easy to } \\
\text { look for products. }\end{array}$ & .813 & & \\
\hline & $\begin{array}{l}\text { Customers can easily use the products in Cosmetic } \\
\text { brand shop. }\end{array}$ & .802 & & \\
\hline \multirow{5}{*}{ Atmosphere of Store } & The temperature of Cosmetic brand shop is proper. & .814 & \multirow{5}{*}{$\begin{array}{c}3.613 \\
(6.243)\end{array}$} & \multirow{5}{*}{.827} \\
\hline & The light of Cosmetic brand shop is bright. & .805 & & \\
\hline & The air of Cosmetic brand shop is fresh. & .793 & & \\
\hline & The sound of music in Cosmetic brand shop is proper. & .768 & & \\
\hline & Cosmetic brand shop is not crowded. & .729 & & \\
\hline
\end{tabular}

(Table 2 continued on next page) 
(Table 2 continued)

\begin{tabular}{|c|c|c|c|c|}
\hline Measurement & Measurement Item & $\begin{array}{l}\text { Factor } \\
\text { Loading }\end{array}$ & $\begin{array}{l}\text { Eigenvalue } \\
(\%)\end{array}$ & Cronbach's $\alpha$ \\
\hline \multirow{4}{*}{ Availability of Tester } & Customers can directly test Cosmetic brand shop. & .836 & \multirow{4}{*}{$\begin{array}{c}3.241 \\
(6.074)\end{array}$} & \multirow{4}{*}{.819} \\
\hline & $\begin{array}{l}\text { Customers can directly test make-up such as mascara, } \\
\text { shadow, brush, lip, and eyeliner in Cosmetic brand shop. }\end{array}$ & .812 & & \\
\hline & $\begin{array}{l}\text { Cosmetic brand shop supplies information that } \\
\text { customers can test the products. }\end{array}$ & .796 & & \\
\hline & $\begin{array}{l}\text { Cosmetic brand shop has a product assortment with } \\
\text { convenient use of self-test machine. }\end{array}$ & .764 & & \\
\hline \multirow{5}{*}{ Proficiency of Consultant } & $\begin{array}{l}\text { The consultant of Cosmetic brand shop explains } \\
\text { carefully the characteristic of goods. }\end{array}$ & .819 & \multirow{5}{*}{$\begin{array}{c}3.165 \\
(6.058)\end{array}$} & \multirow{5}{*}{.808} \\
\hline & $\begin{array}{l}\text { The consultant of Cosmetic brand shop explains } \\
\text { carefully the efficiency of goods. }\end{array}$ & .803 & & \\
\hline & $\begin{array}{l}\text { The consultant of Cosmetic brand shop explains } \\
\text { carefully the information of make-up trend. }\end{array}$ & .802 & & \\
\hline & $\begin{array}{l}\text { The consultant of Cosmetic brand shop explains } \\
\text { carefully the way of skin care. }\end{array}$ & .794 & & \\
\hline & $\begin{array}{l}\text { The consultant of Cosmetic brand shop has a lot of } \\
\text { knowledge on products. }\end{array}$ & .775 & & \\
\hline
\end{tabular}

\subsubsection{Confirmatory Factor Analysis}

In order to find contradictions between hypotheses, based on the previous studies and data (Anderson \& Gerbing, 1998), we statistically re-examined discriminant validity and convergent validity and conducted confirmatory factor analysis after reviewing exploratory factor analysis and reliability verification of the sample data. Not a single item was deleted, as all the factor scores of significant level of measured variables' were under 0.001 . Below Table 3 is the result of confirmatory factor analysis.

Table 3. Confirmatory Factor Analysis

\begin{tabular}{|c|c|c|c|c|c|c|c|c|c|}
\hline \multicolumn{10}{|l|}{ Panel A. } \\
\hline \multicolumn{2}{|c|}{ Construct } & Factor & $\begin{array}{l}\text { Standardized } \\
\text { estimate }\end{array}$ & t value & $\begin{array}{c}\text { Cronbach's } \\
\alpha\end{array}$ & $\mathbf{r}$ & $\mathbf{r}^{2}$ & AVE & C.R \\
\hline \multirow{12}{*}{$\begin{array}{l}\text { Brand } \\
\text { Experience of } \\
\text { Cosmetic } \\
\text { Brand Shop }\end{array}$} & \multirow{3}{*}{$\begin{array}{l}\text { Sensory } \\
\text { Experience }\end{array}$} & SEN 1 & .798 & 9.471 & \multirow{3}{*}{.808} & \multirow{3}{*}{.537} & \multirow{3}{*}{.288} & \multirow{3}{*}{.586} & \multirow{3}{*}{.849} \\
\hline & & SEN 3 & .750 & 9.445 & & & & & \\
\hline & & SEN 4 & .746 & 9.361 & & & & & \\
\hline & \multirow{3}{*}{$\begin{array}{l}\text { Affective } \\
\text { Experience }\end{array}$} & AFF 1 & .797 & 9.521 & \multirow{3}{*}{.818} & \multirow{3}{*}{.549} & \multirow{3}{*}{.301} & \multirow{3}{*}{.592} & \multirow{3}{*}{.854} \\
\hline & & AFF 2 & .761 & 9.438 & & & & & \\
\hline & & AFF 4 & .750 & 9.151 & & & & & \\
\hline & \multirow{4}{*}{$\begin{array}{l}\text { Intellectual } \\
\text { Experience }\end{array}$} & INT 1 & .783 & 9.372 & \multirow{4}{*}{.826} & \multirow{4}{*}{.406} & \multirow{4}{*}{.165} & \multirow{4}{*}{.573} & \multirow{4}{*}{.839} \\
\hline & & INT 2 & .769 & 9.241 & & & & & \\
\hline & & INT 3 & .741 & 9.139 & & & & & \\
\hline & & INT 4 & .733 & 9.008 & & & & & \\
\hline & \multirow{2}{*}{$\begin{array}{l}\text { Behavioral } \\
\text { Experience }\end{array}$} & ACT 1 & .787 & 9.285 & \multirow{2}{*}{.809} & \multirow{2}{*}{.515} & \multirow{2}{*}{.265} & \multirow{2}{*}{.603} & \multirow{2}{*}{.862} \\
\hline & & ACT 2 & .766 & 9.147 & & & & & \\
\hline \multirow{8}{*}{\multicolumn{2}{|c|}{$\begin{array}{l}\text { Feminine Brand Identity of } \\
\text { Cosmetic Brand Shop }\end{array}$}} & CBF 1 & .810 & 10.385 & \multirow{8}{*}{.823} & \multirow{8}{*}{.554} & \multirow{8}{*}{.307} & \multirow{8}{*}{.549} & \multirow{8}{*}{.758} \\
\hline & & CBF 2 & .798 & 10.291 & & & & & \\
\hline & & CBF 3 & .768 & 10.127 & & & & & \\
\hline & & CBF 4 & .739 & 10.004 & & & & & \\
\hline & & CBF 5 & .719 & 9.993 & & & & & \\
\hline & & CBF 6 & .704 & 9.839 & & & & & \\
\hline & & CBF 7 & .698 & 9.742 & & & & & \\
\hline & & CBF 8 & .675 & 9.572 & & & & & \\
\hline
\end{tabular}

(Table 3 continued on next page) 
(Table 3, Panel A continued)

\begin{tabular}{|c|c|c|c|c|c|c|c|c|}
\hline Construct & Factor & $\begin{array}{c}\text { Standardized } \\
\text { estimate }\end{array}$ & t value & $\begin{array}{c}\text { Cronbach's } \\
\alpha\end{array}$ & $\mathbf{r}$ & $\mathbf{r}^{2}$ & AVE & C.R \\
\hline \multirow{8}{*}{$\begin{array}{l}\text { Environmental-Friendly Brand } \\
\text { Identity of Cosmetic Brand } \\
\text { Shop }\end{array}$} & CBE 1 & .824 & 9.252 & \multirow{8}{*}{.803} & \multirow{8}{*}{.602} & \multirow{8}{*}{.362} & \multirow{8}{*}{.599} & \multirow{8}{*}{.792} \\
\hline & CBE 2 & .814 & 9.160 & & & & & \\
\hline & CBE 3 & .793 & 8.885 & & & & & \\
\hline & CBE 4 & .765 & 8.726 & & & & & \\
\hline & CBE 5 & .761 & 8.518 & & & & & \\
\hline & CBE 6 & .757 & 8.437 & & & & & \\
\hline & CBE 7 & .743 & 8.251 & & & & & \\
\hline & CBE 8 & .729 & 8.039 & & & & & \\
\hline \multirow{5}{*}{$\begin{array}{l}\text { Level of Iconic } \\
\text { Product }\end{array}$} & CHP 1 & .829 & 10.134 & \multirow{5}{*}{.828} & \multirow{5}{*}{.529} & \multirow{5}{*}{.280} & \multirow{5}{*}{.613} & \multirow{5}{*}{.869} \\
\hline & CHP 2 & .802 & 10.004 & & & & & \\
\hline & CHP 3 & .783 & 9.863 & & & & & \\
\hline & CHP 4 & .762 & 9.567 & & & & & \\
\hline & CHP 5 & .736 & 9.237 & & & & & \\
\hline \multirow{5}{*}{ Level of Steady-Seller Product } & CSP 1 & .815 & 10.119 & \multirow{5}{*}{.805} & \multirow{5}{*}{.627} & \multirow{5}{*}{.393} & \multirow{5}{*}{.515} & \multirow{5}{*}{.748} \\
\hline & CSP 2 & .801 & 10.106 & & & & & \\
\hline & CSP 3 & .763 & 9.931 & & & & & \\
\hline & CSP 4 & .729 & 9.825 & & & & & \\
\hline & CSP 5 & .711 & 9.695 & & & & & \\
\hline \multirow{4}{*}{$\begin{array}{l}\text { Reasonability of } \\
\text { Price }\end{array}$} & CRP 1 & .806 & 10.015 & \multirow{4}{*}{.794} & \multirow{4}{*}{.525} & & & \\
\hline & CRP 2 & .763 & 9.827 & & & & & \\
\hline & CRP 3 & .738 & 9.726 & & & $.2 / 6$ & ו/ & .142 \\
\hline & CRP 4 & .728 & 9.642 & & & & & \\
\hline & CEL 1 & .809 & 10.219 & & & & & \\
\hline Convenience of & CEL 2 & .793 & 10.162 & & & & & \\
\hline Store Location & CEL 3 & .753 & 9.963 & .817 & .549 & .301 & 1 & / \\
\hline & CEL 4 & .734 & 9.831 & & & & & \\
\hline & CBS 1 & .809 & 10.385 & & & & & \\
\hline Quality of Additional & CBS 2 & .784 & 10.291 & 814 & & & & \\
\hline Service & CBS 3 & .738 & 10.127 & .814 & .554 & .307 & .589 & .751 \\
\hline & CBS 4 & .735 & 10.004 & & & & & \\
\hline & CPA 1 & .847 & 10.134 & & & & & \\
\hline $\begin{array}{l}\text { Efficiency of Product } \\
\text { Assortment }\end{array}$ & CPA 2 & .816 & 10.004 & .836 & .629 & .397 & .676 & .918 \\
\hline & CPA 3 & .804 & 9.863 & & & & & \\
\hline & CSA 1 & .817 & 10.119 & & & & & \\
\hline & CSA 2 & .808 & 10.106 & & & & & \\
\hline Atmosphere of & CSA 3 & .795 & 9.931 & .827 & .527 & .278 & .615 & .771 \\
\hline & CSA 4 & .768 & 9.825 & & & & & \\
\hline & CSA 5 & .731 & 9.695 & & & & & \\
\hline & CST 1 & .836 & 10.015 & & & & & \\
\hline Availability of & CST 2 & .812 & 9.827 & 819 & 525 & 276 & 644 & 792 \\
\hline Tester & CST 3 & .796 & 9.726 & .819 & .525 & .210 & .044 & .192 \\
\hline & CST 4 & .764 & 9.642 & & & & & \\
\hline & CSC 1 & .819 & 10.219 & & & & & \\
\hline & CSC 2 & .803 & 10.162 & & & & & \\
\hline Proficiency of & CSC 3 & .802 & 9.963 & .807 & .549 & .301 & .638 & .788 \\
\hline & CSC 4 & .794 & 9.831 & & & & & \\
\hline & CSC 5 & .775 & 9.526 & & & & & \\
\hline
\end{tabular}

\section{Panel B.} $\chi^{2}(\mathbf{d f})$ $\mathrm{p}>0.05$ 531.771 (d. $f=226, p=.000)$
GFI

$\geqq 0.90$

.915
AGFI

$\geqq 0.80$

.857

RMR
$\leqq 0.08$
.063

CFI

$\geqq 0.90$

.909
RMSEA

$\leqq 0.08$

.054 
As indicated in Table 3, it is necessary to study $\chi 2$, GFI, AGFI, RMR, CFI, and RMSEA in order to check adequacy of deducting each scale's optimal composition of each item. The result shows that the value of $\chi^{2}$ does not meet the standard, but the majority of models fit index demonstrating satisfactory model fit: $0.915,0.857,0.063,0.909$, and 0.054 , respectively. Cronbach's alpha coefficient was used and every utilized factor for measurement was over 0.7 , standard of internal consistency according to Nunnally \& Berstein (1994), to verify internal consistency of each construct. Moreover, we tested C.R (convergent reliability) and AVE (average variance extracted). As a result, we found that the constructs exceeded the standard value ( $C R>0.7, \mathrm{AVE}>0.5)$, and confirmed that every measured item had convergent validity (Hair, Anderson, Babin, \& Black, 2005). Discriminant validity usually refers to the condition when the value of average variance extracted for each factor is greater than the square value of two factors' coefficient. As you can refer to Table 3, when every factor's average variance extracted values exceeded square value of correlation coefficient, it is confirmed to have discriminant validity.

\subsection{Hypothesis Test}

Before conducting hypothesis test about structural equation modeling, we evaluated the research model's suitability. The result of the research model's adequacy is as follows in Table 4.

Table 4. Model Fit

\begin{tabular}{c|c|c|c|c|c}
\hline$\chi^{\mathbf{2}}$ (df) & GFI & AGFI & RMR & CFI & RMSEA \\
\hline $\mathrm{p}>0.05$ & $\geqq 0.90$ & $\geqq 0.80$ & $\leqq 0.08$ & $\geqq 0.90$ & $\leqq 0.08$ \\
\hline $\begin{array}{c}529.697 \\
(\mathrm{~d} . \mathrm{f}=224, \mathrm{p}=.000)\end{array}$ & .917 & .859 & .064 & .908 & .056 \\
\hline
\end{tabular}

The result of the model fit is indicated in the following: $\chi^{2}=529.697$ (d.f $=224, \mathrm{p}=0.000$ ), GFI $=0.917, \mathrm{AGFI}=0.859$, $\mathrm{CFI}=0.908, \mathrm{RMR}=0.064$, RMSEA $=0.056 . \chi^{2}$ is a bit slow the standard but it is so far possible to analyze the research model (Hair et al., 2005). Structural equation model was founded on the path coefficient from feminine brand identity, environmental-friendly identity, the level of iconic product, the level of steady-seller product, reasonable price, the convenience of store location, the quality of additional service, the efficiency of product assortment, the atmosphere of store, the availability of tester, and the proficiency of consultant to brand experience. The following Table 5 is the synthesis of hypothesis test results. 
Table 5. Hypothesis Test Results

\begin{tabular}{|c|c|c|c|c|c|c|}
\hline & Hypothesis & $\begin{array}{c}\text { Path } \\
\text { Coefficient }\end{array}$ & $\begin{array}{c}\text { Standardized } \\
\text { Path Coefficient }\end{array}$ & t value & $p$ value & Result \\
\hline $\mathrm{H} 1$ & $\begin{array}{l}\text { Feminine Brand Identity- } \\
\text { Brand Experience }\end{array}$ & $.230^{* * *}$ & .355 & 3.376 & .000 & Accept \\
\hline $\mathrm{H} 2$ & $\begin{array}{l}\text { Environmental-Friendly Identity- } \\
\text { Brand Experience }\end{array}$ & .075 & .107 & 1.276 & .328 & Reject \\
\hline H3 & $\begin{array}{l}\text { Level of Iconic Product- } \\
\text { Brand Experience }\end{array}$ & $.253^{* * * *}$ & .264 & 3.490 & .000 & Accept \\
\hline $\mathrm{H} 4$ & $\begin{array}{l}\text { Level of Steady-Seller Product- } \\
\text { Brand Experience }\end{array}$ & $.189^{* *}$ & .190 & 2.484 & .005 & Accept \\
\hline H5 & $\begin{array}{l}\text { Reasonability of Price- } \\
\text { Brand Experience }\end{array}$ & .027 & .046 & 0.746 & .684 & Reject \\
\hline H6 & $\begin{array}{l}\text { Convenience of Store Location- } \\
\text { Brand Experience }\end{array}$ & $.280^{* * * *}$ & .292 & 3.921 & .000 & Accept \\
\hline $\mathrm{H} 7$ & $\begin{array}{l}\text { Quality of Additional Service- } \\
\text { Brand Experience }\end{array}$ & $.259^{* * * *}$ & .303 & 3.690 & .000 & Accept \\
\hline $\mathrm{H} 8$ & $\begin{array}{l}\text { Efficiency of Product } \\
\text { Assortment- Brand Experience }\end{array}$ & $.172^{* * *}$ & .228 & 2.376 & .008 & Accept \\
\hline H9 & $\begin{array}{l}\text { Atmosphere of Store- } \\
\text { Brand Experience }\end{array}$ & $.187^{* * *}$ & .192 & 2.476 & .005 & Accept \\
\hline H10 & $\begin{array}{l}\text { Availability of Testers- } \\
\text { Brand Experience }\end{array}$ & $.124^{* *}$ & .153 & 2.257 & .014 & Accept \\
\hline H11 & $\begin{array}{l}\text { Proficiency of Consultants- } \\
\text { Brand Experience }\end{array}$ & $.141^{* *}$ & .168 & 2.317 & .012 & Accept \\
\hline
\end{tabular}

\section{CONCLUSION AND DISCUSSTION}

This section aims to explain the relationship between brand experience providers and brand experience by discussing each brand experience provider in order of influence on brand experience. First, the convenient location of cosmetic brand shops has the most powerful impact on brand experience (path coefficient $=0.280, t=3.921$, $\mathrm{p}=0.000$ ). It indicates that in order to provide full brand experience, the convenient location of a store is imperative because consumers don't have much spare time these days in the fast lifestyle. Consumers decide where to shop considering distance, transportation, etc. Thus, Cosmetic companies should open stores in a major business district where has convenient public transportation and gives an easy access a large floating population.

Second, additional services of cosmetic brand shops affects brand experience positively (path coefficient $=0.259$, $\mathrm{t}=3.690, \mathrm{p}=0.000$ ). That means distinctive additional services of cosmetic brand shops stimulate five senses and consumers have amusement, positive perception, and show favorable responses. With the advance of science technology, the quality and design of products are not a distinctive competitive advantage of companies any more. Therefore, distinctive and unexpected services that are directly provided to consumers play a more important role in companies' successful performance. It suggests that cosmetic businesses should reflect consumer needs, enhance additional services such as skin, nail, and hair care, and differentiate their services from other competitors.

Third, the level of iconic product (path coefficient $=0.253, \mathrm{t}=3.490, \mathrm{p}=0.000$ ) and steady-seller product (path coefficient $=0.189, \mathrm{t}=2,484, \mathrm{p}=0.005$ ) has a positive influence on brand experience. It shows that outstanding design and quality of product can appeal to consumers' multiple senses, create amusement, and promote positive perception and favorable behavior. As the technology develops, the quality and design do not have a significant impact on the uniqueness of companies. However, the results of this research suggest that companies should enhance the quality and design of products by reflecting the latest trends, adding social, psychological, cultural, artistic elements, in an order to differentiate themselves from competitors. For example, functional, protective, practical, aesthetic, and environmental elements can be applied to product design and quality and can be segmented according to markets, in an attempt to develop product designs. 
Fourth, the feminine brand identity of cosmetic brand shops positively affects brand experience (path coefficient $=0.230, t=3.376, p=0.000$ ). However, environmental friendly brand identity of cosmetic brand shops does not have a impact of brand experience (path coefficient $=0.075, \mathrm{t}=1.276, \mathrm{p}=0.328$ ). That means that consumers experience the feminine identity of a brand through store's logo, color, interior, display, brand name, sign, exterior, and other visual and verbal brand identity elements, but not the environmental-friendly identity. For major consumers of cosmetic brands are women, consumers can perceive the brand of a cosmetic brand shop as feminine. But the fact that the environmental-friendly identity of a brand could not be delivered to consumers because of its characteristics - beauty products are directly applied to consumer's skin - is very problematic. The results imply that consumers have a high interest in beauty products because the products are directly applied to their skin. No matter how cosmetic companies utilize their marketing activities, display environmental-friendly visual and verbal elements of brand identity in store in order to promote the fact that their products contain environmental-friendly ingredients, consumers are well-informed by media so that they already know the products have low environmentalfriendly ingredients and do not perceive the environmental-friendly image of cosmetic bran shops. And consumers have a strong idea that beauty products contain many chemicals rather than environmental-friendly ingredients and this idea can prevent consumers from perceiving cosmetic brand shops as environmental-friendly. Thus, cosmetic firms should roll out new product lines with rich environmental-friendly ingredients and change cosmetic containers and packaging into recyclable ones. Moreover, promoting environmental campaign helps consumers to change the idea from considering cosmetic products chemical products to organic products. Store's visual and verbal brand identity elements including product display and environmental-friendly color should couple with using more organic ingredients, environmental campaign, certification mark from the environmental rating agency, as part of an effort to help customers have an environmental-friendly brand experience.

Fifth, the atmosphere of cosmetic brand shops has a positive impact on brand experience (path coefficient $=0.018$, $\mathrm{t}=2.476, \mathrm{p}=0.005$ ). It suggests that temperatures, lights, air, music, uncrowned store environment, and other elements evoke consumer's positive experience. That means the effective use of store's atmosphere elements can evoke favorable consumer experience, leading to consumer's positive perception and purchasing behavior (Baker, Parasuraman, Grewal, \& Voss, 2002). Thus, cosmetic brand shop companies are recommended to strategically promote the atmosphere elements and keep stores pleasant. Cosmetic companies also need to take the store's atmosphere into account for stimulating consumer's curiosity about cosmetic brand shops and constantly look into how consumers perceive the store's atmosphere.

Sixth, the efficiency of product assortment has a positive influence on brand experience (path coefficient $=0.172$, $\mathrm{t}=2.376, \mathrm{p}=0.008$ ). It indicates that the efficient product assortment and open space help consumers easily find products and rapid product transition helps them quickly recognize the latest product trend. In addition, the efficient product assortment leads consumers to have a strong brand image, a change of feeling, intellectual curiosity, and positive behavior. Companies therefore put more importance on product assortment and optimally modify the assortment to satisfy consumers. For example, they can display discount products at the entrance and attract consumers. The assortment of the newest items at the entrance can lead people to buy both discount products and the latest items.

Seventh, the proficiency of cosmetic brand stores' consultants has a positive impact on experience (path coefficient $=0.141, \mathrm{t}=2.317, \mathrm{p}=0.012$ ). It indicates that the brand and the consumer in the cosmetic brand shop, and that the customized and friendly service of the consultant, the employee who directly serves consumers, has a significant influence on consumer's overall brand experience of the cosmetic brand shop. Thus, cosmetic companies should provide intensive training to help store consultants not only nurture their friendly attitude towards consumers, but also be acquainted with products to provide tailored services. In particular, the consultants need to be welltrained in communication because they should provide services in an effortless and comfortable way.

Eighth, the availability of cosmetic testers in cosmetic brand shops positively affect consumers experience of the cosmetic brand shops (path coefficient $=0.124, \mathrm{t}=2,257, \mathrm{p}=0.014$ ). It shows that having opportunities to try out products in stores and self-examining skin care equipment plays a key role in creating overall dimensions of consumers' brand experience of cosmetic brand shops. Because consumers try out products and self-examining equipment in cosmetic brand shops, companies should deliver various opportunities for consumers to have full experience in a friendly atmosphere. Thus, cosmetic firms should dispose manual of self-testing equipment and 
product brochure beside testers for consumers to try out on their own conveniently. Also, they need to train their employees to assist consumers to use those equipment and testers without inconvenience.

However, the reasonability of pricing of cosmetic brand shops does not affect brand experience (path coefficient $=0.027, \mathrm{t}=0.746, \mathrm{p}=0.684$ ). The results imply that consumer's overall brand experience of cosmetic brand shops connote emotional and symbolic dimensions such as sensory, affective, intellectual, and behavioral brand experience so that prices, which are cognitive and functional element, does not affect overall brand experience of cosmetic brand shops. Second, cosmetics are not a choice, but a must. Even though the products are expensive, consumers tend to buy if they are good for their body rather than be concerned about the prices of products. Third, thanks to the globalization, consumers these days are already well aware of prices of cosmetic products in cosmetic brand shops through media so that prices are nothing new to consumers and couldn't be able to evoke consumers' favorable brand experience. Fourth, cosmetic companies sell their products at similar prices so that the prices of products are not influential. Last, consumers lately perceive cosmetic products are unreasonable because many media reports point out the excessive packaging and the gap between the quantity of the product and its price, leading to unfavorable experience of cosmetic brand shops. Therefore, companies are recommended to improve their product ingredients and quantity rather than external factors like excessive packaging and luxurious design of its container in order to help consumers perceive that the prices are reasonable, and change their mind. To this extend, they can pour more effort with the help of not only pricing strategy but also promotions, offers, discount events coupled with sales promotion strategies.

Despite our effort, there are limitations in results and suggestions that are needed further research. First, this study found difficulties in constructing brand experience scale to measure the concepts of unique marketing factors of cosmetic brand shops. However, based on previous studies and thorough review, the scale could have good reliability and validity. We encourage further research to explore and measure the factors that the current scale does not measure through in-depth study on existing research. And in terms of valid scale, further study should investigate how to raise reliability by adding more measurements. Moreover, given that this paper looked into the relationship between the marketing factors of cosmetic brand shops and overall brand experience, further research should examine how these factors are related to the current implementation of companies' marketing strategies. Finally, considering the fact that this research examined cosmetic brand shop brands and the relationship between marketing factors of cosmetic brand shops and overall brand experience, if further research involves broader range of brands and their products and services, it can have more interesting results.

\section{AUTHOR BIOGRAPHIES}

Gap Yeon Jeong (First Author) is a Research Professor in School of Business Administration at Kyungpook National University, South Korea. His research interests include international management and marketing of China, Vietnam, and Brazil and so on.

Chae Chang Im (Corresponding Author) is a Research Assistant of Institute of Global Business Research of Hankuk University of Foreign Studies in Korea. Research interests include International Financial Reporting Standard, fair value accounting, derivatives accounting, and other financial \& managerial accounting issues

Min Suk Kim (Co-Author) is an Instructor in Management and Marketing at Shinhan University, South Korea. She is interested in retail marketing, communication channel and cosmetic brand shop.

\section{REFERENCES}

Aaker, D.A. (1996). Building Strong Brands: What is a Strong Brand? New York: The Free Press.

Anderson, J.C. \& Gerbing, D.W. (1988). Structural equation modeling in practice: A review and recommend two-step approach. Psychological Bulletin, 103(2), 411-423.

Babin, B.J. \& William R.D. (1995). Consumer self-regulation in a retail environment. Journal of Retailing, 71, 47-70.

Backstrom, K. \& Johansson, U. (2006). Creating and consuming experiences in retail store environments: Comparing retailer and consumer perspectives. Journal of Retailing and Consumer Services, 13, 417-430.

Bagdare, S. (2013). Antecedents of retail customer experience. Journal of Marketing \& Communication, 8(3), 45-51. 
Baker, J.V. (1987). The role of the environment in marketing service: The consumer perspective in the service challenge: Integrating for competitive advantage. Czepeil, J. A., J. A. Congram, \& J. Shanahan eds. Chicago: American Marketing Association, 77-84.

Baker, J., Parasuraman, A., Gewal, D. \& Voss, G.B. (2002). The influence of multiple store environment cues on perceived merchandise value and patronage intentions. Journal of Marketing, 66(4), 120-141.

Berry, L.L., Wall, E.A. \& Carbone, L.P. (2006). Service clues and customer assessment of the service experience: Lessons from marketing. Academy of Management Perspectives, 20(2), 43-57.

Bitner, M.J. (1992). Servicescapes: The impact of physical surroundings on customers and employee. Journal of Marketing, $56(2), 57-71$.

Bloemer, J. \& Ldrkerken-Schroder, G. (2002). Store satisfaction and store loyalty explained by customer and store related factors. Journal of Customer Satisfaction, Dissatisfaction and Complaining Behavior, 15(2), 68.

Bonfrer, A. \& Chintagunta, P.K. (2004). Store brands: Who buys them and what happens to retail prices when they are introduced? Review of Industrial Organization, 24(2), 195-218.

Brakus, J. J., Schmitt, B.H. \& Zarantonello, L. (2009). Brand experience: What is it? How is it measured? Does it affect loyalty? Journal of Marketing, 73(3), 52-68.

Cox, A.D., Cox, D. \& Anderson, R.D. (2005). Reassessing the pleasures of store shopping. Journal of Business Research, 58, 250-259.

Davis, L.Y. (2012). Let us go shopping: exploring northwest chinese consumers' shopping experiences. International Journal of Consumer Studies, 37, 353-359.

De Chernatony, L. \& McDonald, M.H.B. (1998). Creating powerful brands in consumer service and industrial markets. Oxford, England: Butterworth-Heinenmann.

Dolbec, P.Y. \& Chebat, J.C. (2013). The impact of a flagship vs. a brand store on brand attitude, brand attachment and brand equity. Journal of Retailing, 89(4), 460-466.

Donovan, R.J. \& Rossiter, J.R. (1982). Store atmosphere: An environmental psychology approach. Journal of Retailing, 58(1), 34-57.

Fitzsimons, G.M., Chartrand, T.L. \& Fitzsimons, G.J. (2008). Automatic effects of brand exposure on motivated behavior: how apply makes you 'think different'. Journal of Consumer Research, 35(6), 21-35.

Grewal, D., Levy, M. \& Kumar, V. (2009). Customer experience management in retailing: An organizing framework. Journal of Retailing, 85(1), 1-14.

Guenzi, P., Johnson, M.D. \& Castaldo, S. (2009). A comprehensive model of customer trust in two retail stores. Journal of Service Management, 20(3), 290-316.

Hagtvedt, H. \& Patrick, V.M. (2008), Art infusion: The influence of visual art on the perception and evaluation of consumer products. Journal of Marketing Research, 45(3), 379-389.

Hair, J.F., Anderson, R.E., Babin, B.J. \& Black, W.C. (2005). Multivariate data analysis. 5th, Upper Saddle River, NJ: PrenticeHall, 654-667.

Hart, C., Farrell, A.M., Stachow, G., Reed, G. \& Cadogan, J.W. (2007). Enjoyment of the shopping experience: Impact on customers' repatronage intentions and gender influence. The Service Industries Journal, 27(5), 583-604.

Heinonen, K. \& Strandvik, T. (2005). Communication as an element of service value. International Journal of Service Industry Management, 16(2), 186-198.

Hoch, S.J. (2002). Product experience is seductive. Journal of Consumer Research, 29(3), 448-454.

Holloway, B.B. \& Beatty, S.E. (2008). Satisfiers and dissatisfiers in the online environments: A critical incident assessment. Journal of Service Research, 10(4), 347-364.

Hopkins, C.D., Grove, S.J., Raymond, M.A. \& LaForge, M.C. (2009). Designing the e-servicescape: implications for online retailers. Journal of Internet Commerce, 8(1-2), 23-43.

Iglesias, O., Singh, J.J. \& Batista-Foguet, J.M. (2011). The role of brand experience and affective commitment in determining brand loyalty. Brand Management, 18(8), 570-582.

Ishida, C. \& Taylor, S.A. (2012). Retailing brand experience, brand experience congruence, and consumer satisfaction. Journal of Consumer Satisfaction, Dissatisfaction and Complaining Behavior, 1, 63-79.

Ismail, A.R. (2011). Experience marketing: An empirical investigation. Journal of Relationship Marketing, 10, $167-201$.

Jain, R. \& Bagdare, S. (2009). Determinants of customer experience in new format retail stores. Journal of Marketing and Communication, 5(2), 34-44.

Jones, M. A. (1999). Entertaining shopping experience: An exploratory investigation. Journal of Retailing and Consumer Services, 6, 129-139.

Kapferer, J.N. (1997). Strategic brand management: Creating and sustaining brand equity. 2nd, London: Kogan Page.

Keller, K.L. (2008). Strategic brand management: Building, measuring, and managing brand equity. 3rd, Upper Saddle River, NJ: Prentice Hall.

Keller, K.L. (2009). Building strong brands in a modern marketing communication environment. Journal of Marketing Communication, 15(2-3), 139-155.

Kelley, S.W. \& Hoffman, K.D. (1997). An investigation of positive affect, proposal behaviors and service quality. Journal of Retailing, 73, 407-427. 
Kerin, R.A., Jin, A. \& Howard, D.J. (1992). Store shopping experience and consumer price-quality-value perceptions. Journal of Retailing, 68(4), 376-397.

Klaus, P. \& Maklan, S. (2007). The role of brands in a service-dominated world. Journal of Brand Management, 15(2), 115-122.

Knutson, B.J. \& Beck, J.A. (2003). Identifying the dimensions of the experience construct: Development of the model. Journal of Quality Assurance in Hospitality \& Tourism, 4(3/4), 23-35.

Kotler, P. (1973). Atmospherics as a marketing tool. Journal of Retailing, 49(4), 48-64.

Lee, H.J. \& Kang, M.S. (2012). The effect of brand experience on brand relationship quality. Academy of Marketing Studies Journal, 16(1), 87-98.

Lin, I.Y. (2010). The combined effect of color and music on customer satisfaction in hotel bars. Journal of Hospitality Marketing \& Management, 19(1), 22-37.

Meyer, C. \& Schwager, A. (2007). Understanding customer experience. Harvard Business Review, 55(2), 117-126.

Morgan-Thomas, A. \& Veloutsou, C. (2011). Beyond technology acceptance: Brand relationships and online brand experience. Journal of Business Research, 7, 1-7.

Namasivayam, K. \& Mattila, A.S. (2007). Accounting for the servicescapes and service exchange on consumers' satisfaction evaluations. Journal of Hospitality \& Tourism Research, 31(1), 3-18.

Nunnally, J.C. \& Berstein, I.H. (1994). Psychometric theory. 3rd, New York: McGraw-Hill.

Ofir, C. \& Simonson, I. (2007). The effect of stating expectations on consumer satisfaction and shopping experience. Journal of Marketing Research, 44(1), 164-174.

Orth, U.R. \& Malkewitz, K. (2008). Holistic package design and consumer brand impressions. Journal of Marketing, 72(5), 6481.

O' Sullivan, E.L. \& Spangler, K.J. (1998). Experience marketing: Strategies for the New Millennium. State College, PA: Venture Publishing. Inc.

Page, S.J. \& Connell, J. (2006). Tourism: A modern synthesis. London, England: Thomson.

Payne, A., Storbacka, K., Frow, P. \& Knox, S. (2009). Co-creating brands: Diagnosing and designing the relationship experience. Journal of Business Research, 62, 379-389.

Roswinanto, W. (2011). Investigating antecedents and consequences of brand experience in advertising contexts, American marketing association. Summer Educators' Conference Proceedings, 22, 431.

Ruzzier, K.M. \& De Chernatony, L. (2013). Developing and applying a place brand identity model: The case of Slovenia. Journal of Business Research, 66(1), 45-52.

Schmitt, B.H. (1999). Experiential marketing: how to get customers to sense, feel, think, act, relate to your company and brands. New York: The Free Press.

Schmitt, B.H. (2003). Customer experience management. New York: John Wiley \& Sons.

Soars, B. (2009). Driving sales through shoppers' sense of sound, sight, smell and touch. International Journal of Retail \& Distribution Management, 37(3), 286-298.

Sullivan, M. \& Adcock, D. (2002). Retail marketing. Stanford, CT: Cengage learning EMEA.

Terblanche, N. \& Boshoff, C. (2004). The in-store shopping experience: Comparative study of supermarket and clothing store customers. South African Journal of Business Management, 35, 1-10.

Thomson, M., MacInnis, D. J. \& Park, C.W. (2005). The ties that bind: Measuring the strength of consumer's emotional attachments to brand. Journal of Consumer Psychology, 15(1), 77-91.

TNEX (Think Nears) (2012). A Report on The Competitiveness Reinforcement of Aritaum. Amorepacific.

Verhoef, P.C., Lemon, K.N., Parasuraman, A., Roggeveen, A., Tsiros, M. \& Schlesinger, L.A. (2009). Customer experience creation: Determinants, dynamics and management strategies. Journal of Retailing, 85(1), 31-41.

Veryzer Jr., R.W. \& Hutchinson, J.W. (1998). The influence of unity and prototypicality on aesthetic response to new product designs. Journal of Consumer Research, 24(4), 374-393.

Vilnai-Yavets, I. \& Rafaeli, A. (2006). Aesthetics and professionalism of virtual servicescapes. Journal of Service Research, $8(3), 245-259$.

Wakefield, K.L. \& Blodgett, J.G. (1996). The effect of the servicescape on customers behavioral intentions in leisure service settings. Journal of Service Marketing, 19(6), 45-61.

Zarantonello, L. \& Schmitt, B.H. (2013). The impact of event marketing on brand equity: The mediating roles of brand experience and brand attitude. International Journal of Advertising, 32(2), 255-280.

Zarantonello, L., Schmitt, B.H. \& Brakus, J.J. (2007). Development of the brand experience scale. Advances on Consumer Research, 34, 580-582. 